\title{
26. AGE DISTRIBUTION OF VOLCANISM ALONG ASEISMIC RIDGES IN THE EASTERN INDIAN OCEAN $^{1}$
}

\author{
Robert A. Duncan ${ }^{2}$
}

\begin{abstract}
Concordant plateau and isochron ages are obtained from ${ }^{40} \mathrm{Ar}-{ }^{39} \mathrm{Ar}$ incremental heating experiments on volcanic rocks recovered by drilling at three Leg 121 sites along the Ninetyeast Ridge and two dredge locations on the southern scarp of the Broken Ridge, eastern Indian Ocean. The new data confirm a northerly increase in the age of volcanism along the Ninetyeast Ridge, from 38 to 82 $\mathrm{Ma}$; this lineament links current hotspot volcanism near the Kerguelen islands with the Rajmahal flood basalt eruptions at M0 time (117 $\pm 1 \mathrm{Ma})$. The Broken Ridge was formed over the same hotspot at 88-89 Ma, but later experienced rift-related volcanism in Paleocene time $(63 \mathrm{Ma})$. The geometry and distribution of ages along these prominent volcanic ridges and the MascareneChagos-Laccadive-Maldive ridge system in the western Indian Ocean are most compatible with plate motions over fixed hotspots near Kerguelen and Réunion islands, respectively.
\end{abstract}

\section{INTRODUCTION}

A major thrust of the Indian Ocean drilling program was to examine the behavior of mantle plumes, expressed by numerous prominent volcanic ridges, plateaus, and seamount chains. In this ocean basin, more clearly than in the slower-spreading Atlantic or the subduction-ringed Pacific, the volcanic record of plumeborn hotspots is preserved intact, from the massive outpourings of flood basalts marking the initiation of hotspot activity to discrete intraplate ocean island volcanoes. The geometry and age distribution of the volcanism along these traces allow kinematic aspects of mantle plumes to be deciphered, while the compositions of erupted basaltic material reveal the interplay of various mantle source regions for melting. This chapter is concerned with the time frame of volcanism for the two major elevated volcanic structures in the eastern Indian Ocean: the Broken Ridge and the Ninetyeast Ridge. A companion chapter reporting the age distribution of volcanism for the trail of the Réunion hotspot in the western Indian Ocean is included in the Scientific Results of Leg 115 (Duncan and Hargraves, 1990).

The Ninetyeast Ridge, the Broken Ridge, the Kerguelen-Heard Plateau, and the Rajmahal Traps (eastern India) are all volcanic products of a long-lived hotspot located near the Kerguelen archipelago (Luyendyck, 1977; Luyendyck and Rennick, 1977; Duncan, 1978; Morgan, 1981; Duncan, 1981). The rationale for connecting these volcanic elements to a common origin involves (1) a temporal pattern of increasing ages to the north along the Ninetyeast Ridge (von der Borch, Sclater, et al., 1974; Davies, Luyendyck, et al., 1974; Duncan, 1978) to the Rajmahal Traps (Baksi, 1986), (2) constant paleolatitudes of Ninetyeast Ridge basalts (Peirce, 1978), (3) compositional similarities among the members (Frey et al., 1977; Whitford and Duncan, 1978; Mahoney et al., 1983), and (4) plausible plate tectonic histories which could bring each volcanic structure over the Kerguelen hotspot at appropriate times during the last 120 m.y. (Morgan, 1981). Early Cretaceous basalts dredged (LeClaire et al., 1987) and drilled

${ }^{1}$ Weissel, J., Peirce, J., Taylor, E., Alt, J., et al., 1991. Proc. ODP, Sci. Results, 121: College Station, TX (Ocean Drilling Program).

${ }^{2}$ College of Oceanography, Oregon State University, Corvallis, OR 97331, U.S.A. from the southern Kerguelen Plateau during Legs 119 and 120 (Barron, Larsen, et al., 1989; Schlich, Wise, et al., 1989) confirm that this element of the hotspot track formed early, perhaps as a conjugate to the Rajmahal Traps.

Until now the volcanic history of the Broken Ridge has been conjectural, constrained principally to be older than the Santonian $(\geq 87 \mathrm{Ma}$ ) basal sediments recovered at Deep Sea Drilling Project Site 255 (Davies, Luyendyck, et al., 1974). However, a prolonged history of rifting from the Kerguelen-Heard Plateau followed by initially slow seafloor spreading between the Australian and Antarctic plates (Mutter and Cande, 1983) could have produced volcanic activity ranging from $>87$ to $45 \mathrm{Ma}$ along the southern margin of the Broken Ridge. Dredged basalts (Robert Conrad site survey cruise $\mathrm{RC} 2708$ ) from this escarpment now provide a direct means for establishing the age of the volcanic foundation of the Broken Ridge.

While the general northerly increase in ages along the Ninetyeast Ridge has been appreciated for some time, this lineament is over $5000 \mathrm{~km}$ long and the three latest sites drilled during Leg 121 add considerable detail to the history of plate motions with respect to the Kerguelen hotspot. In particular, the issue of hotspot fixity can now be addressed with considerable precision by comparing hotspot tracks in the Atlantic and Indian Ocean basins for the period 0-120 Ma. More regionally, increased definition of Cenozoic plate motions will be used to define the collisional history of the Himalayan orogeny and the sedimentary and tectonic development of the surrounding basins (Klootwijk et al., this volume).

\section{SAMPLE DESCRIPTIONS}

\section{Broken Ridge}

The Broken Ridge is a fragment of a large volcanic plateau rifted from the northeastern edge of the Kerguelen Plateau in mid-Eocene time (Royer et al., this volume). The ridge has an asymmetric profile, sloping gently to the north but having a steep southern escarpment formed by normal faulting. Surveys for the final selection of drilling sites for Leg 121 were conducted during Robert Conrad cruise RC2708 in August 1986. During this cruise basaltic rocks were dredged from two locations along the southern scarp of the Broken Ridge (Fig. 1). Samples were initially examined in hand specimen by F. Frey (M.I.T.) to distinguish lithologies and thin sections made of representative pieces. The most 


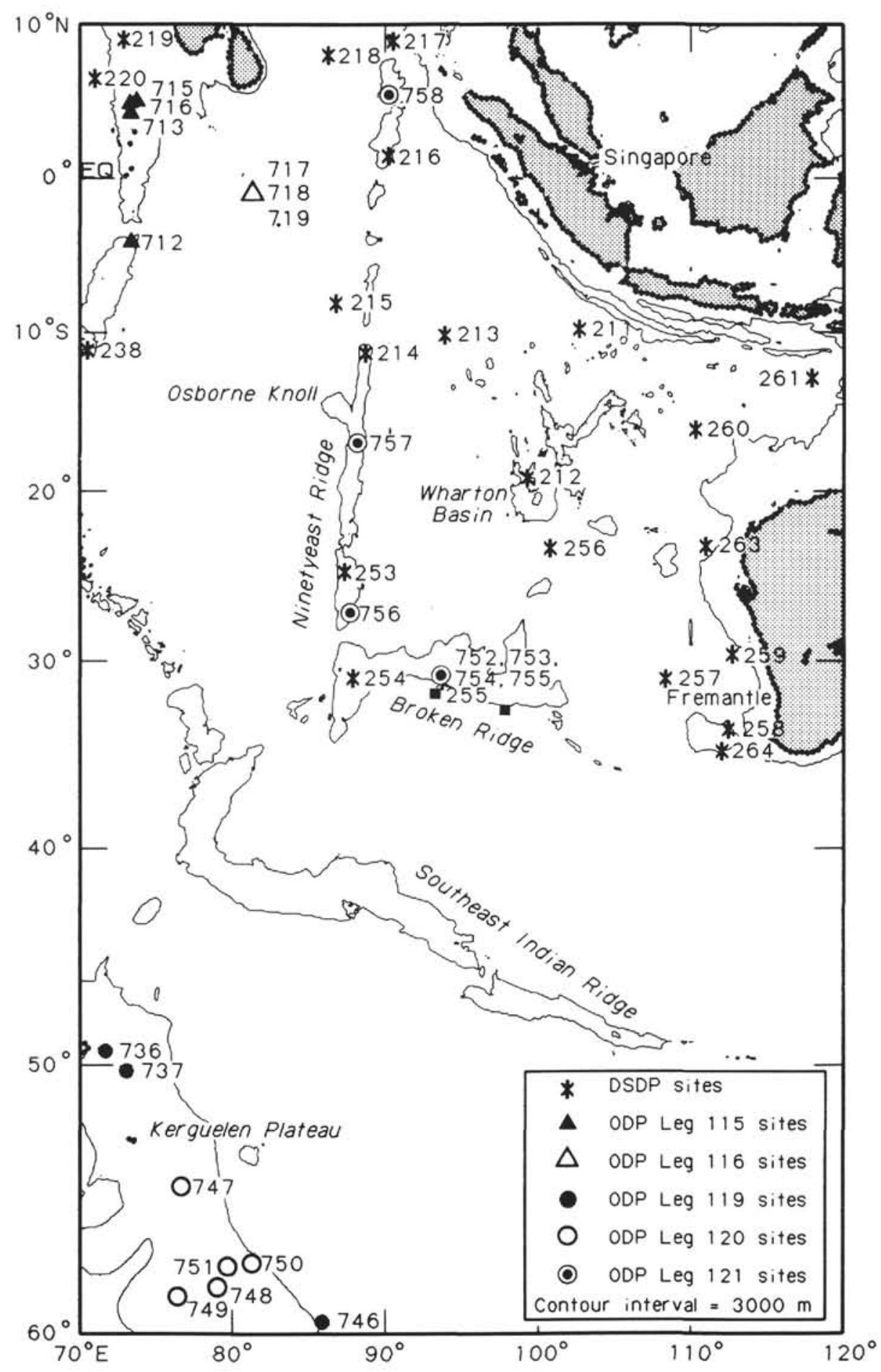

Figure 1. Bathymetric features of the eastern Indian Ocean, including locations of Leg 121 drilling sites along the Ninetyeast Ridge, and dredges from the Broken Ridge (solid squares).

promising samples were then selected by W. B. Jones (M.I.T.) and forwarded to Oregon State University, where a final screening of thin sections led to suitable samples for radiometric analyses.

Relatively fresh basalts were found in the volcanic material from each of the three dredges. Sample 8E1 is a fine-grained, aphyric basalt, with microlites of plagioclase in a partially crys- tallized groundmass. Rare vesicles are partly filled with clays and there is patchy replacement of the groundmass with clays. Sample 9-1 is an aphyric, fine-grained basalt with moderate alteration of groundmass to brown-green clays and zeolites. Sample 10-1 is a fine-grained, well-crystallized, compact basalt with occasional phenocrysts of fresh plagioclase. Clinopyroxene in the ground- 
mass is variably altered to brown clays ( $10 \%$ of rock). Sample $10-2$ is a medium-grained basalt with occasional vesicles filled with clays; brown-green clays have replaced $\sim 15 \%$ of the groundmass. Sample 10D3 is a well-crystallized, medium-grained basalt with glomerocrysts of plagioclase $(2 \mathrm{~mm})$ and smaller clinopyroxene and olivine phenocrysts. Alteration is restricted to iddingsite partially replacing olivine.

\section{Ninetyeast Ridge}

Samples were selected for age determinations from cored basalts at each of the three Leg 121 drill sites on the Ninetyeast Ridge (Fig. 1). Two specimens from each site were chosen from the freshest available material, as judged from examination of thin sections, and from the widest range in composition, as determined from shipboard chemical analyses (Peirce, Weissel, et al., 1989). Details of site stratigraphy are also presented in Peirce, Weissel, et al. (1989).

Basalts from Hole 756D are fine-grained but well-crystallized, with occasional phenocrysts of plagioclase set in a feldspathic matrix of trachytic texture. Vesicles are common and are partially lined with clays. Individual flows are separated by layers including tephra and basaltic rubble, largely changed to red soil with montmorillonite clay and hematite, indicating subaerial eruptions. The lowermost sedimentary unit is a hard, upper Eocene limestone containing planktonic foraminifers and nannofossils. Overlying this are soft calcareous sediments deposited in an upper bathyal environment, suggesting rapid early subsidence of the volcano. Sample 121-756D-7R-2, 144-149 cm, is a well-crystallized, largely aphyric basalt that shows pervasive oxidation and partial alteration of groundmass to brown clays, characteristic of incipient subaerial laterization. Sample 121-756D-12R-2, 98-102 $\mathrm{cm}$, is also well-crystallized, somewhat more feldspathic, and alteration is to patchy green clays ( $15 \%$ of rock). Basalts from Hole $757 \mathrm{C}$ also appear to have been erupted subaerially, as judged from the considerable thickness of phreatically erupted ashes overlying the vesicular flows. The upper Paleocene sediments immediately above the basalt indicate a very shallow depositional environment that quickly deepened to bathyal depths by early Eocene time. The basalt flows here are thin, vesicular, and variably altered (especially around vesicles and veins). Samples 121 757C-9R-1, 30-34 cm, and 121-757C-12R-1, 124-128 cm, both contain fresh feldspar phenocrysts set in a fine-grained groundmass. Blue-green clays and zeolites have replaced this matrix in patches. These two samples come from geochemically distinct units.

At the northernmost site basalts from Hole $758 \mathrm{~A}$ were recovered beneath tuffaceous chalks of Campanian age. There was no evidence that these basalts were erupted subaerially; units include ponded sheet flows and thinner alternating sheet and pillowed flows, characterized by sharp, glassy selvages. Interbedded ashes indicate a nearby subaerial eruptive center. The basalts are medium-grained and aphyric to sparsely plagioclase and clinopyroxene phyric. Vesicularity is variable but shipboard chemical analyses did not reveal more that one compositional type. Samples 121-758A-62R-1, 135-138 cm, and 121-758A-69R-5, 98-102 $\mathrm{cm}$, are well-crystallized but pervasively altered (as much as $50 \%$ of the rock) along microfractures and as infilling in vesicles to clays, zeolites, and calcite. A large fraction of the groundmass clinopyroxene in Sample 121-758A-69R-5, 98-102 cm, has been replaced by green clays. The basalts from this site exhibit the most extensive low temperature seawater alteration of those examined in this study.

\section{ANALYTICAL METHODS}

Samples selected for radiometric analyses from thin-section examination and preliminary geochemical data were crushed to 0.5 - to $1-\mathrm{mm}$ chips, ultrasonically washed in distilled water, and dried in a warm oven. Approximately $1-\mathrm{g}$ splits of these prepared chips were sealed in evacuated quartz tubes and irradiated for 8 $\mathrm{hr}$ in the core of the Oregon State University TRIGA reactor, where they received a dose of $\sim 8 \times 10^{17}$ neutron-volts. The efficiency of conversion of ${ }^{39} \mathrm{~K}$ to ${ }^{39} \mathrm{Ar}$ by neutron capture was monitored with samples of hornblende standard Mmhb-1 (520 $\mathrm{Ma}$; Samson and Alexander, 1987). Further details of the flux characteristics, monitor minerals, sample loadings, and corrections for interfering $\mathrm{K}$ - and $\mathrm{Ca}$-derived $\mathrm{Ar}$ isotopes are given in Dalrymple et al. (1981).

Argon extractions for the incremental heating experiments were performed in a conventional glass extraction line using radio-frequency induction heating following bakeout at $175^{\circ} \mathrm{C}$ (Dalrymple and Lanphere, 1969). Heating steps were determined from previous experience to divide the total sample argon into six roughly equal portions. Samples were held at each step setting (temperature) for $30 \mathrm{~min}$. The argon composition of each gas increment was measured mass spectrometrically at Oregon State University with an AEI MS-10S instrument.

After corrections for background, mass fractionation, and isotopic interferences, the ${ }^{40} \mathrm{Ar}-{ }^{39} \mathrm{Ar}$ incremental heating data were reduced as both age spectra and ${ }^{36} \mathrm{Ar} /{ }^{40} \mathrm{Ar}$ vs. ${ }^{39} \mathrm{Ar} /{ }^{40} \mathrm{Ar}$ isochrons; the results appear in Table 1 and Figures 2-10. For these analyses the system background was $5 \times 10^{-16}$ moles ${ }^{36} \mathrm{Ar}$. Individual step ${ }^{40} \mathrm{Ar} /{ }^{36} \mathrm{Ar}$ and ${ }^{40} \mathrm{Ar} /{ }^{39} \mathrm{Ar}$ compositions can be seen in the isochron plots; typical analytical uncertainties on the isotopic ratios were $0.5 \%-1 \%$. Large amounts of radiogenic ${ }^{40} \mathrm{Ar}$ were measured for all samples except those from Site 758, where low $\mathrm{K}$-contents and more extensive alteration (clays and zeolites) probably contributed to near-atmospheric ${ }^{40} \mathrm{Ar} /{ }^{36} \mathrm{Ar}$ values (and, consequently, large calculated age uncertainties). Complete incre-

Table $1 .{ }^{40} \mathrm{Ar}-{ }^{39} \mathrm{Ar}$ plateau and isochron ages from the Ninetyeast and Broken Ridges, eastern Indian Ocean.

\begin{tabular}{|c|c|c|c|c|c|c|c|c|}
\hline \multirow{2}{*}{$\begin{array}{l}\text { Sample } \\
\text { number }\end{array}$} & \multicolumn{2}{|c|}{ Plateau age $\pm 1 \sigma(\mathrm{Ma})$} & \multirow{2}{*}{$\begin{array}{c}{ }^{39} \mathrm{Ar} \\
(\% \text { of total })\end{array}$} & \multirow{2}{*}{$\begin{array}{l}\text { Integrated age } \\
\text { (Ma) }\end{array}$} & \multirow{2}{*}{$\begin{array}{l}\text { Isochron age } \\
\pm 1 \sigma(\mathrm{Ma})\end{array}$} & \multirow[b]{2}{*}{$\mathrm{N}$} & \multirow{2}{*}{$\begin{array}{l}\text { SUMS } \\
(\mathrm{N}-2)\end{array}$} & \multirow{2}{*}{$\begin{array}{c}{ }^{40} \mathrm{Ar} /{ }^{36} \mathrm{Ar} \\
\text { intercept }\end{array}$} \\
\hline & (wt by $1 / \sigma^{2}$ ) & (wt by $\left.\% 0^{39} \mathrm{Ar}\right)$ & & & & & & \\
\hline RC2708, DR-8E1b & $89.2 \pm 0.4$ & $88.0 \pm 4.9$ & 57.5 & 76.4 & $87.1 \pm 1.1$ & 4 & 1.0 & $292.2 \pm 3.4$ \\
\hline RC2708, DR-9-1 & \multicolumn{2}{|c|}{ (none developed) } & & 56.0 & & & & \\
\hline RC2708, DR-10-1 & $88.1 \pm 0.8$ & $88.3 \pm 1.2$ & 53.5 & 74.7 & $88.4 \pm 1.3$ & 5 & 1.1 & $285.4 \pm 3.3$ \\
\hline RC2708, DR-10-2 & $62.1 \pm 0.3$ & $62.0 \pm 0.5$ & 65.0 & 58.3 & $62.7 \pm 0.9$ & 4 & 1.7 & $283.5 \pm 7.4$ \\
\hline RC2708, DR-10D3 & $83.2 \pm 1.9$ & $83.5 \pm 5.5$ & 42.1 & 59.7 & $83.0 \pm 3.1$ & 4 & 1.1 & $284.8 \pm 5.1$ \\
\hline 121-756D-7R-2, 144-149 & $42.0 \pm 0.6$ & $41.6 \pm 1.3$ & 65.8 & 32.4 & $43.3 \pm 1.5$ & 5 & 1.8 & $292.7 \pm 2.3$ \\
\hline $121-756 \mathrm{D}-12 \mathrm{R}-2,98-102$ & $44.5 \pm 0.7$ & $43.8 \pm 1.5$ & 100.0 & 43.8 & $42.1 \pm 0.7$ & 5 & 0.1 & $299.9 \pm 3.4$ \\
\hline $121-757 \mathrm{C}-9 \mathrm{R}-1,30-34$ & \multicolumn{2}{|c|}{ (none developed) } & & 59.1 & & & & \\
\hline $121-757 \mathrm{C}-12 \mathrm{R}-1,124-128$ & $55.6 \pm 0.4$ & $55.5 \pm 0.7$ & 57.3 & 57.8 & $57.9 \pm 1.6$ & 3 & 1.5 & $268.2 \pm 15.8$ \\
\hline $121-758 \mathrm{~A}-62 \mathrm{R}-1,135-138$ & $80.7 \pm 3.5$ & $84.3 \pm 12.5$ & 59.4 & 76.3 & $71.3 \pm 7.6$ & 6 & 10.7 & $295.8 \pm 0.3$ \\
\hline $121-758 \mathrm{~A}-69 \mathrm{R}-5,98-102$ & $83.1 \pm 3.9$ & $81.4 \pm 7.6$ & 86.8 & 73.1 & $83.4 \pm 2.4$ & 5 & 0.2 & $295.5 \pm 0.3$ \\
\hline
\end{tabular}

Notes: Corrected for ${ }^{37} \mathrm{Ar}$ decay, half-life $=35.1$ days. $\lambda \epsilon=0.581 \times 10^{-10} \mathrm{yr}^{-1} ; \lambda \beta=4.962 \times 10^{-10} \mathrm{yr}^{-1}$. 
mental heating data as well as additional plateau and isochron diagrams can be obtained from the author on request. Apparent $\mathrm{Ca} / \mathrm{K}$ ratios were calculated for each step argon composition using the relationship $\mathrm{Ca} / \mathrm{K}=1.852{ }^{37} \mathrm{Ar} /{ }^{\beta 9} \mathrm{Ar} \mathrm{mol} / \mathrm{mol}$ (Fleck et al., 1977; Walker and McDougall, 1982).

Step argon compositions were integrated for plateau ages if they formed a well-defined, high-temperature sequence of contiguous heating increments, representing more than $50 \%$ of the total ${ }^{39} \mathrm{Ar}$, whose calculated ages were statistically indistinguishable (at the $1 \sigma$ level). Step ages were combined to calculate plateau ages in two ways (Table 1). The first method followed Dalrymple et al. (1988) in weighting each step age by the inverse of its variance to arrive at a weighted mean. This calculated mean more closely reflects, then, the more precisely determined step ages (generally those with larger amounts of radiogenic ${ }^{40} \mathrm{Ar}$ ). The second method weights each step by the proportion of the total gas $\left(\%{ }^{39} \mathrm{Ar}\right)$ represented by that step, without allowing for differences in analytical errors. This approach is more conservative in that the calculated standard errors are larger than for the first method but otherwise there are no significant differences between the two sets of estimates.

Isochron ages have been determined from ${ }^{36} \mathrm{Ar} /{ }^{40} \mathrm{Ar}$ vs. ${ }^{39} \mathrm{Ar} /{ }^{40} \mathrm{Ar}$ correlation diagrams. Unlike the age spectrum (plateau) plots that assume an initial ${ }^{40} \mathrm{Ar} /{ }^{36} \mathrm{Ar}$ composition equal to atmosphere, the correlation diagrams allow determination of the sample age and initial ${ }^{40} \mathrm{Ar} /{ }^{36} \mathrm{Ar}$ composition independently (see McDougall and Harrison, 1988, for a complete discussion). In such diagrams only those steps that plot collinearly are used in isochron calculations. For most samples (see discussion below for exceptions) the ${ }^{40} \mathrm{Ar} /{ }^{36} \mathrm{Ar}$ intercept is near atmospheric composition, which justifies the assumption in calculating plateau ages. The goodness-of-fit parameter SUMS (York, 1969) has a $\chi^{2}$-distribution with ( $\mathrm{N}-2)$ degrees of freedom, $\mathrm{N}$ being the number of steps included in the isochron regression. For reference, a value of SUMS $/(\mathrm{N}-2)=2.6$ for a regression fit with $\mathrm{N}=5$ would indicate that an isochron relationship for the step argon compositions could not be dismissed at the $95 \%$ confidence limit. Experiments that yield such an acceptable measure of goodness-of-fit, near atmospheric ${ }^{40} \mathrm{Ar} /{ }^{36} \mathrm{Ar}$ intercept, and relatively concordant isochron and plateau ages are likely to have identified reliable crystallization ages (Lanphere and Dalrymple, 1978).

\section{DISCUSSION OF AGE DETERMINATIONS}

All of the samples from the Broken and Ninetyeast ridges produced disturbed ${ }^{40} \mathrm{Ar}-{ }^{39} \mathrm{Ar}$ age spectra characteristic of finegained basalts that have suffered variable alteration at low temperature, which is attributed to nonconcordant loss of radiogenic ${ }^{40} \mathrm{Ar}$ (during alteration) and ${ }^{39} \mathrm{Ar}$ (during neutron irradiation) from alteration minerals. One sample (121-757C-9R-1, 30-34 $\mathrm{cm}$ ) showed reactor-induced ${ }^{39} \mathrm{Ar}$ recoil (Turner and Cadogan, 1974; Huneke and Smith, 1976), which redistributed ${ }^{39} \mathrm{Ar}$ to produce erroneously young ages for (K-rich) high temperature steps and erroneously old ages for (K-poor) low temperature steps in this fine-grained sample. For most samples the middle-to-high temperature portions of the gas released, however, displayed concordant (although somewhat irregular) plateaus. Integrated ages, calculated by recombining the argon compositions of all steps (Table 1), are generally younger than the plateau and isochron ages, indicating that radiogenic ${ }^{40} \mathrm{Ar}$ has been lost from the groundmass during clay formation. At least two samples from each locality have been analyzed so that results can be compared for consistency.

Walker and McDougall (1982) have shown the utility in calculating $\mathrm{Ca} / \mathrm{K}$ ratios from the ${ }^{37} \mathrm{Ar} /{ }^{39} \mathrm{Ar}$ compositions of individual gas increments to indicate the minerals responsible for release of argon from the whole rock samples within given temperature intervals. Mineral data for partially altered basalts show a range in $\mathrm{Ca} / \mathrm{K}$ : clinopyroxenes $(500-2000)$, plagioclase feldspar $(20$ $500)$, glass $(5-20)$, and clays $(0.1-5)$. Plots of $\mathrm{Ca} / \mathrm{K}$ against $\%{ }^{39} \mathrm{Ar}$ for these experiments (Figs. 2-10) show $\mathrm{Ca} / \mathrm{K}$ increasing with temperature, from values less than 1 to over 300. Argon compositions from low temperature steps yield $\mathrm{Ca} / \mathrm{K}=1-5$, indicative of clay alteration phases (smectite, celadonite). Middle temperature steps show $\mathrm{Ca} / \mathrm{K}=10-60$ (glass and feldspar), while at high temperatures $(\mathrm{Ca} / \mathrm{K}=100-300)$ gas was released primarily from feldspar; there appears to be little ${ }^{39} \mathrm{Ar}$ contribution from pyroxenes, owing to the low $\mathrm{K}$-content of that mineral. The gas increments which define the plateau ages, then, were released strictly from the igneous phases within the samples and so constitute crystallization ages.

Four samples from the two dredging locations on Broken Ridge and five samples from the three drilling sites on the Ninetyeast Ridge produced acceptable crystallization ages. For these experiments plateau ages and isochron ages are concordant. The plateau ages (weighted by $1 / \sigma^{2)}$ are generally more precisely determined and, when the best-fit ${ }^{40} \mathrm{Ar} /{ }^{36} \mathrm{Ar}$ intercepts are near atmospheric composition, we can be assured that these are valid crystallization ages.

Broken Ridge sample RC2708 8E1 (Fig. 2) developed a convincing plateau age of $88-89 \mathrm{Ma}$ and concordant isochron age $(87.1 \pm 1.1 \mathrm{Ma})$. Sample RC2708 9-1 did not develop a plateau but showed a monotonically increasing age spectrum, reaching a maximum step age of $78 \mathrm{Ma}$. Hence, the integrated age (56 Ma) is a minimum age and probably well below the true crystallization age. Samples RC2708 10-1, 10-2, and 10D3 (Figs. 3-5) produced acceptable plateau ages (although the 10D3 plateau is based on only two step ages comprising $42 \%$ of the total gas released). Two separate crystallization ages appear to emerge: an older mid-Cretaceous age around $88 \mathrm{Ma}(10-1)$, extending perhaps to $83 \mathrm{Ma}$ (10D3), which matches the age from sample 8E1, and a younger Paleocene age (62-63 Ma) from sample 10-2 (Fig. 4). It is likely that the older age is an original formation age for the Broken Ridge while the younger age represents a volcanic event related to early rifting between the Broken Ridge and Kerguelen-Heard Plateau (Mutter and Cande, 1983). In this case, we might expect to see some compositional differences between the two age groups.

At the southern Ninetyeast Ridge drilling site two samples produced acceptable plateau ages of $42-44 \mathrm{Ma}$ (Figs. 6, 7). It is possible that a significant age difference exists between the samples but this conclusion is not warranted by the age data. The best estimate of the site age is the mean of the two plateau ages (43.2 $\pm 0.5 \mathrm{Ma}$ ). This age is compatible with the age of the lowermost overlying sediments (late Eocene) but somewhat younger than the age predicted from modeling plate motions over fixed hotspots (48-50 Ma, Fig. 11). The evidence that these basalts were erupted subaerially could also indicate that they are late-stage lavas, produced several million years after the main shield-building phase of volcanism.

Sample 121-757C-12R-1, 124-128 cm (Fig. 8), exhibits a Paleocene age. The isochron fit (based on only 3 points) yielded a ${ }^{40} \mathrm{Ar} /{ }^{36} \mathrm{Ar}$ intercept below the atmospheric value (295.5). If the isochron were forced to an intercept of 295.5 , which is reasonable given the subaerial formation, a slightly older isochron age would obtain ( $59 \mathrm{Ma}$ ). The age spectrum plot shows a reasonable plateau, but some suggestion of a ${ }^{39} \mathrm{Ar}$-recoil pattern, in which case the plateau may be ambiguous. Given that plateau and isochron ages are not strictly concordant, the age at this site is somewhat problematic. Unfortunately, the second sample analyzed produced a recoil pattern and the only age estimate is the integrated age of 59.1 Ma. Considering all the age information the site age must be 
A Basalt RC27-08, 8E1

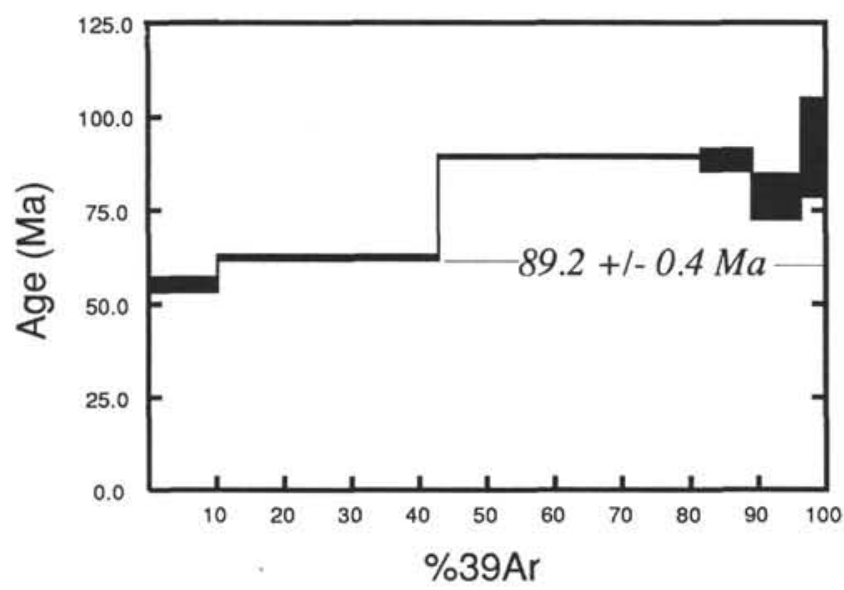

B Basalt RC27-08, 8E1

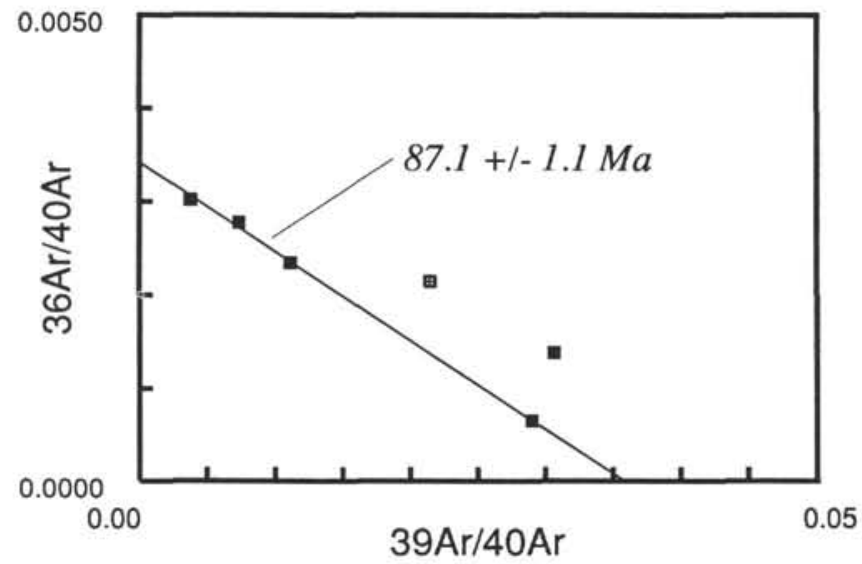

C Basalt RC27-08, 8E1

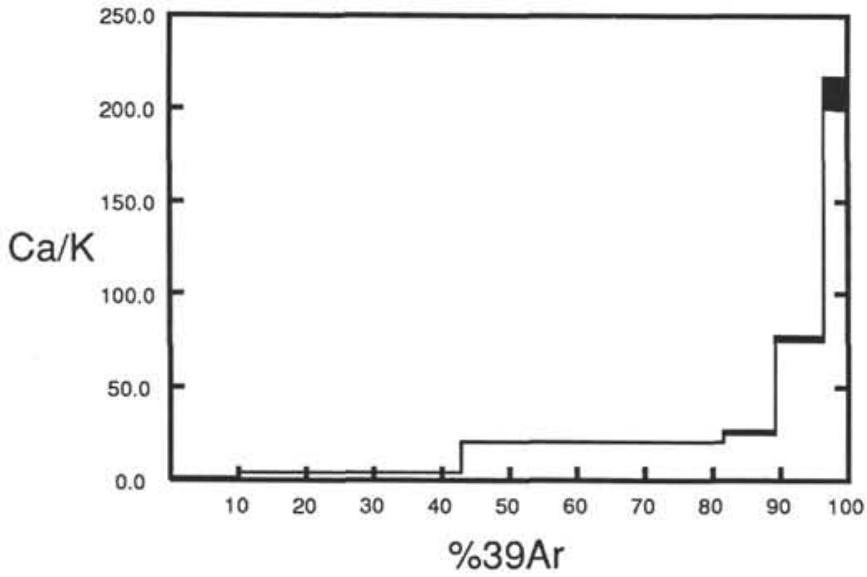

Figure 2. A. Apparent age spectrum (plateau) diagram. B. ${ }^{36} \mathrm{Ar} /{ }^{40} \mathrm{Ar}-{ }^{39} \mathrm{Ar} /{ }^{40} \mathrm{Ar}$ isochron diagram. C. Apparent $\mathrm{Ca} / \mathrm{K}$ release diagram for basalt sample $\mathrm{RC} 2708$ $8 \mathrm{E} 1$ from the Broken Ridge. Horizontal boxes in the gas release plots indicate the estimated analytical error $(\sim 1 \sigma)$ about each calculated step age or $\mathrm{Ca} / \mathrm{K}$. A plateau age (Table 1) has been determined from the weighted mean of contiguous, concordant gas increment ages (steps 3-6). The isochron age has been determined from the best-fitting line to collinear gas increment compositions (filled squares) after York (1969). Ca/K compositions reflect the minerals outgassing as a function of temperature.
A Basalt RC27-08, 10-1

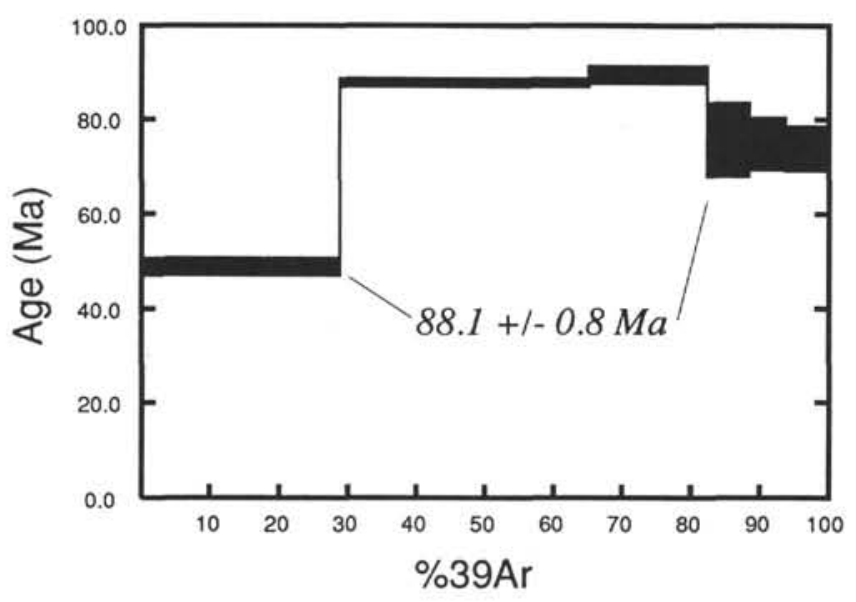

B Basalt RC27-08, 10-1

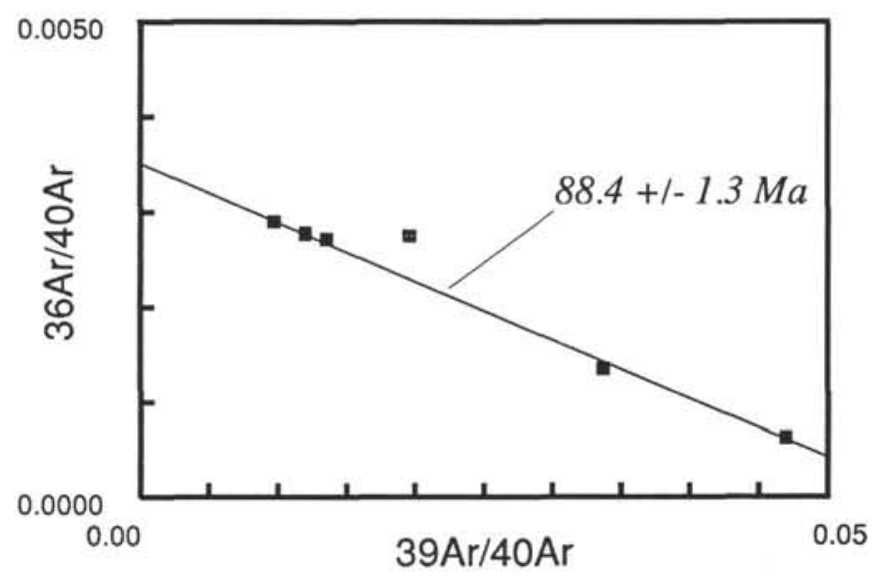

c Basalt RC27-08, 10-1

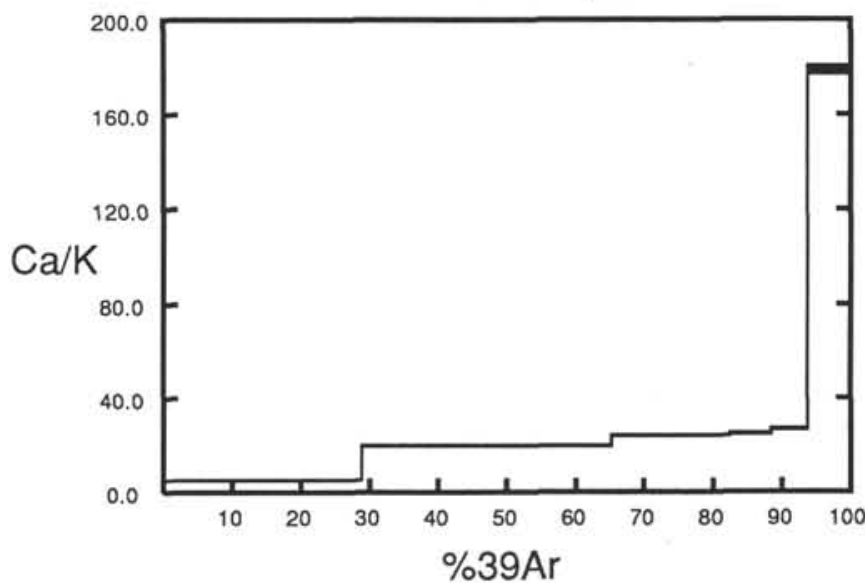

Figure 3. A. Apparent age spectrum (plateau) diagram. B. ${ }^{36} \mathrm{Ar} /{ }^{40} \mathrm{Ar}-{ }^{39} \mathrm{Ar} /{ }^{40} \mathrm{Ar}$ isochron diagram. C. Apparent $\mathrm{Ca} / \mathrm{K}$ release diagram for basalt sample $\mathrm{RC} 2708$ 10-1 from the Broken Ridge. Details as in Figure 2. 
A Basalt RC27-08, 10-2

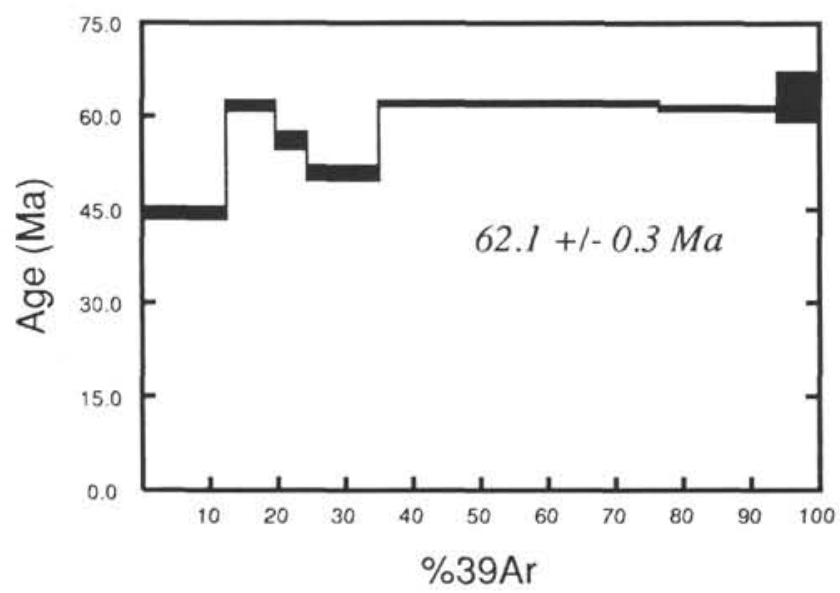

B Basalt RC27-08, 10-2

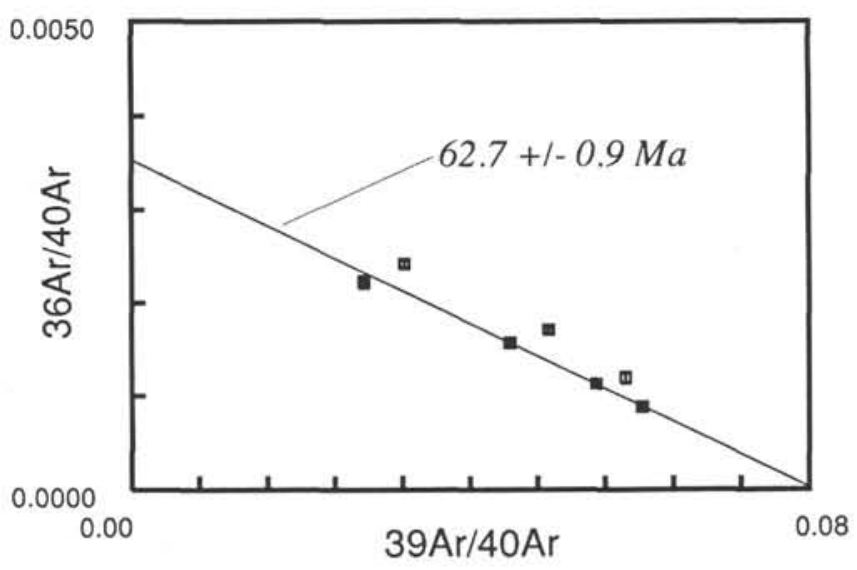

c Basalt RC27-08, 10-2

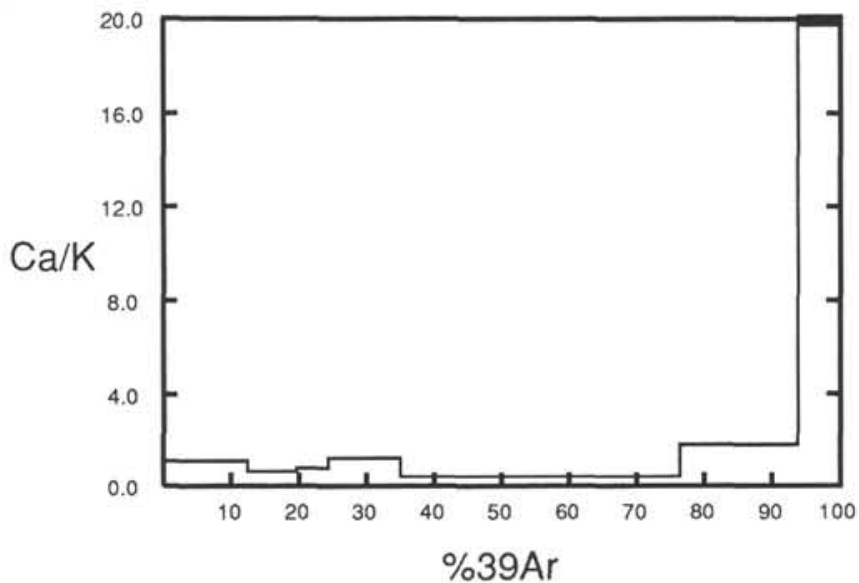

Figure 4. A. Apparent age spectrum (plateau) diagram. B. ${ }^{36} \mathrm{Ar} /{ }^{40} \mathrm{Ar}-{ }^{39} \mathrm{Ar} /{ }^{40} \mathrm{Ar}$ isochron diagram. C. Apparent $\mathrm{Ca} / \mathrm{K}$ release diagram for basalt sample $\mathrm{RC} 2708$ 10-2 from the Broken Ridge. Details as in Figure 2.
A Basalt RC27-08, 10D3

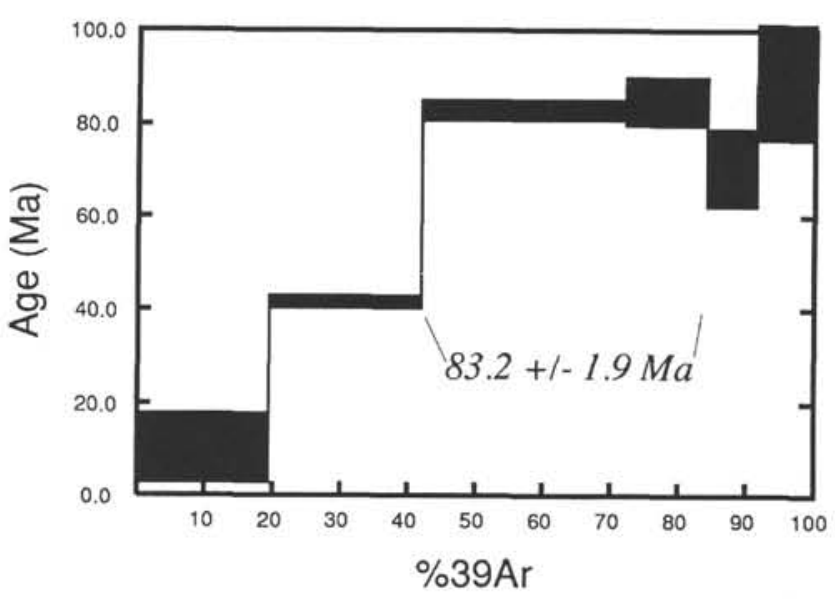

B Basalt RC27-08, 10D3

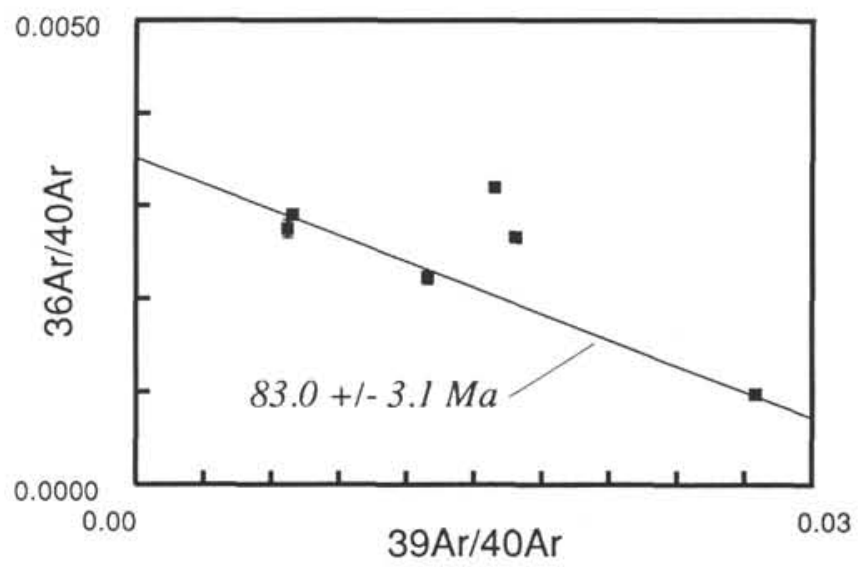

c Basalt RC27-08, 10D3

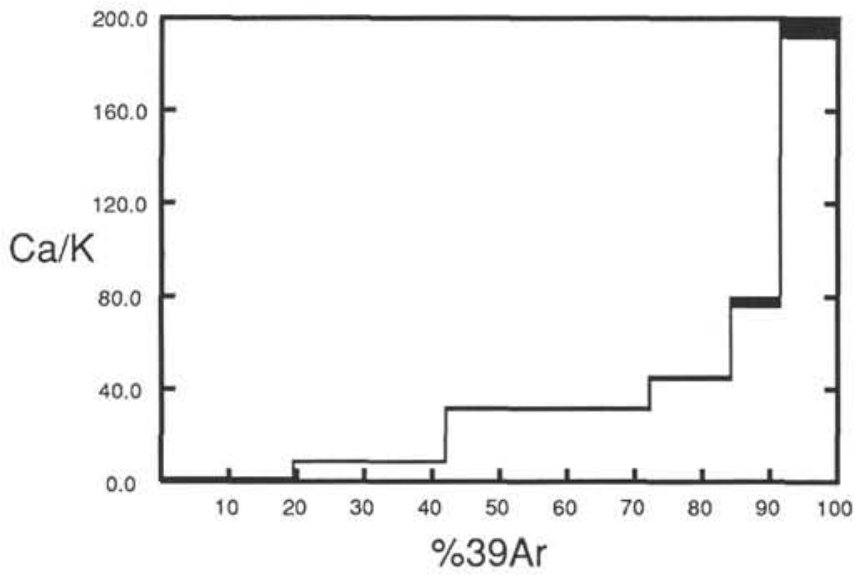

Figure 5. A. Apparent age spectrum (plateau) diagram. B. ${ }^{36} \mathrm{Ar} /{ }^{40} \mathrm{Ar}-{ }^{39} \mathrm{Ar} /{ }^{40} \mathrm{Ar}$ isochron diagram. C. Apparent $\mathrm{Ca} / \mathrm{K}$ release diagram for basalt sample $\mathrm{RC} 2708$ 10D3 from the Broken Ridge. Details as in Figure 2. 


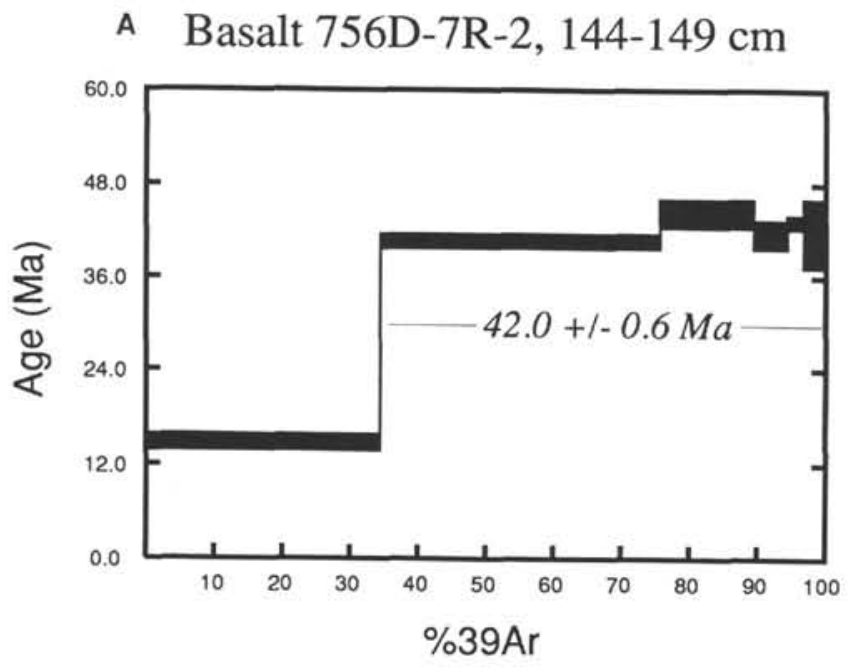

B Basalt 756D-7R-2, 144-149 cm

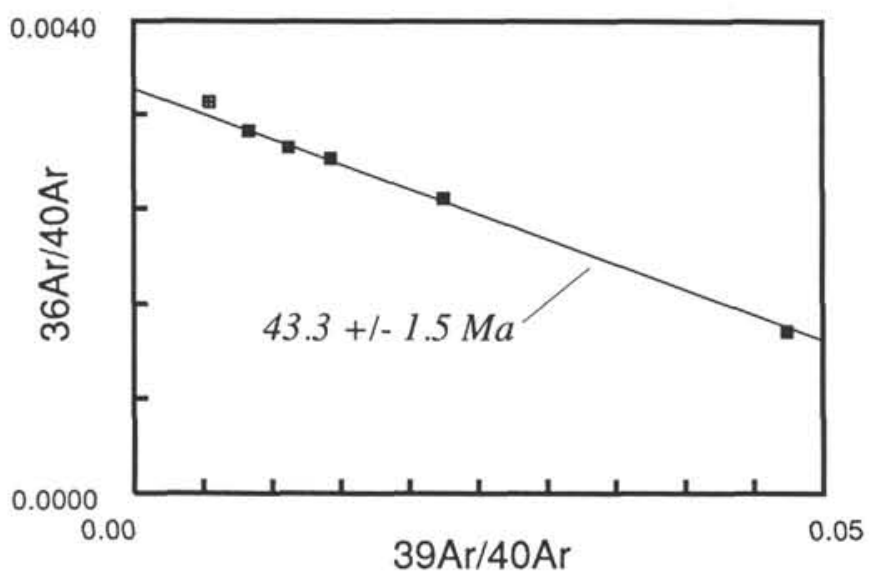

C Basalt 756D-7R-2, 144-149 cm

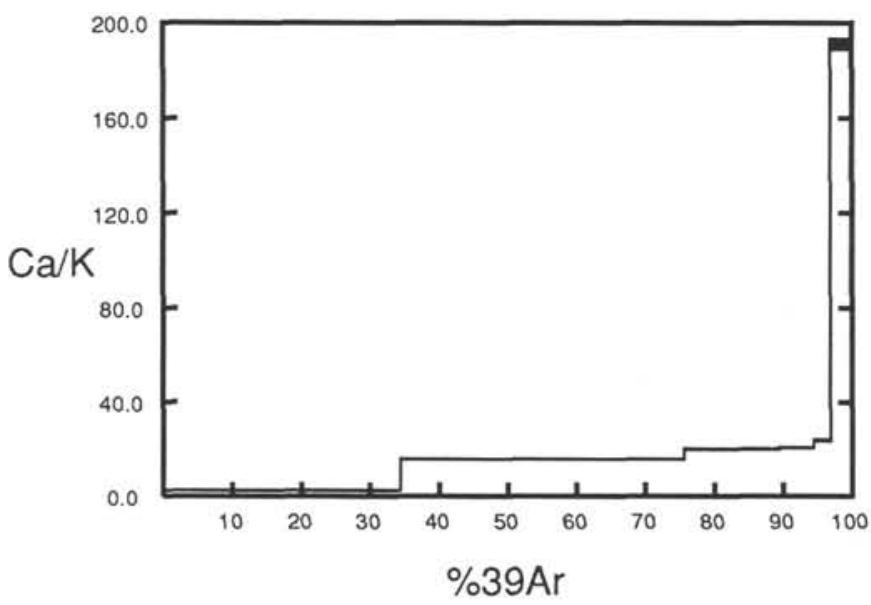

Figure 6. A. Apparent age spectrum (plateau) diagram. B. ${ }^{36} \mathrm{Ar} /{ }^{40} \mathrm{Ar}-{ }^{-39} \mathrm{Ar} /{ }^{40} \mathrm{Ar}$ isochron diagram. C. Apparent $\mathrm{Ca} / \mathrm{K}$ release diagram for basalt Sample 121756D-7R-2, 144-149 cm, from the Ninetyeast Ridge. Details as in Figure 2.
A Basalt 756D-12R-2, 98-102 cm

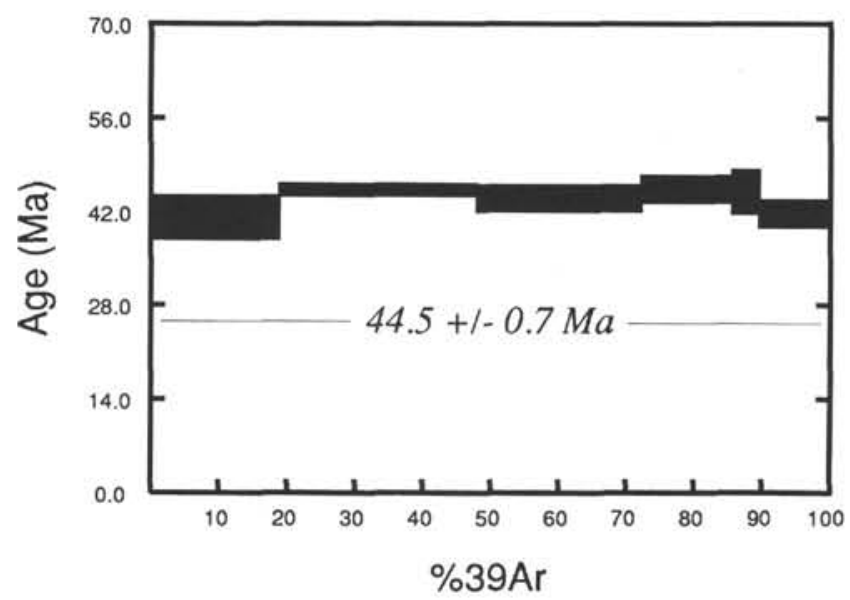

B Basalt 756D-12R-2, 98-102 cm

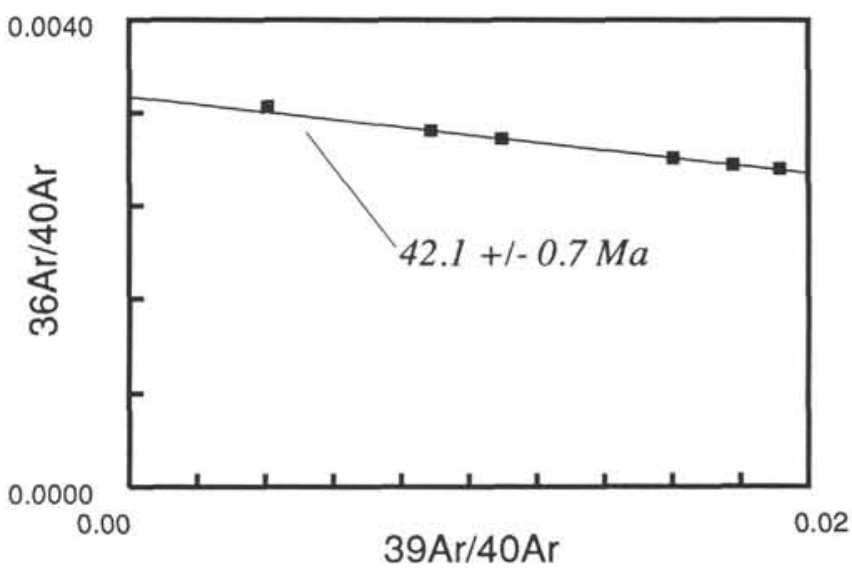

C Basalt 756D-12R-2, 98-102 cm

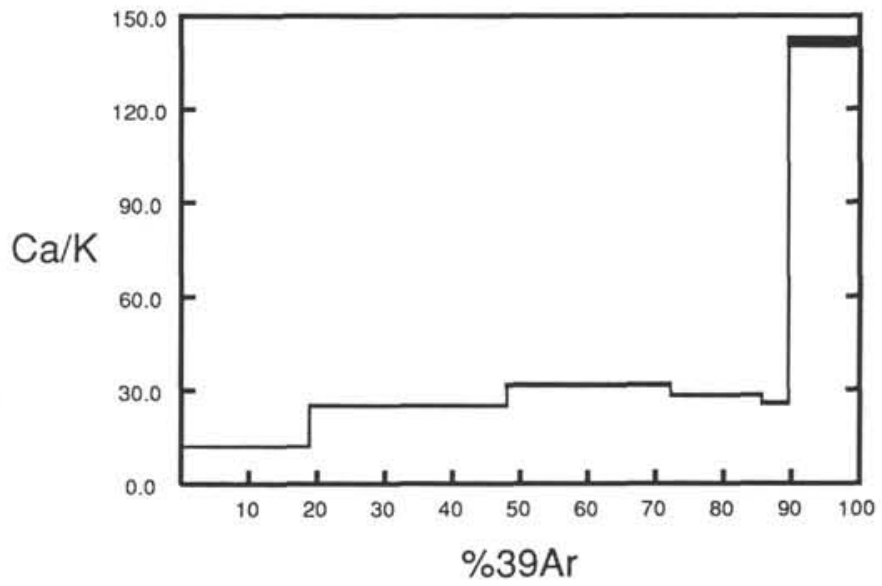

Figure 7. A. Apparent age spectrum (plateau) diagram. B. ${ }^{36} \mathrm{Ar} /{ }^{40} \mathrm{Ar}-{ }^{39} \mathrm{Ar} /{ }^{40} \mathrm{Ar}$ isochron diagram. C. Apparent $\mathrm{Ca} / \mathrm{K}$ release diagram for basalt Sample 121756D-12R-2, 98-102 cm, from the Ninetyeast Ridge. Details as in Figure 2. 


\section{A Basalt 757C-12R-1, 124-128 cm}

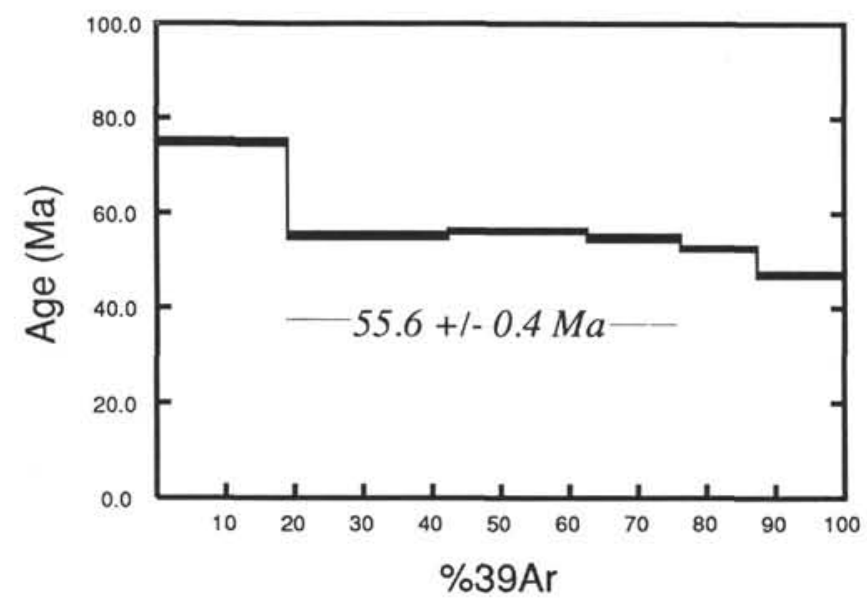

\section{B Basalt 757C-12R-1, 124-128 cm}

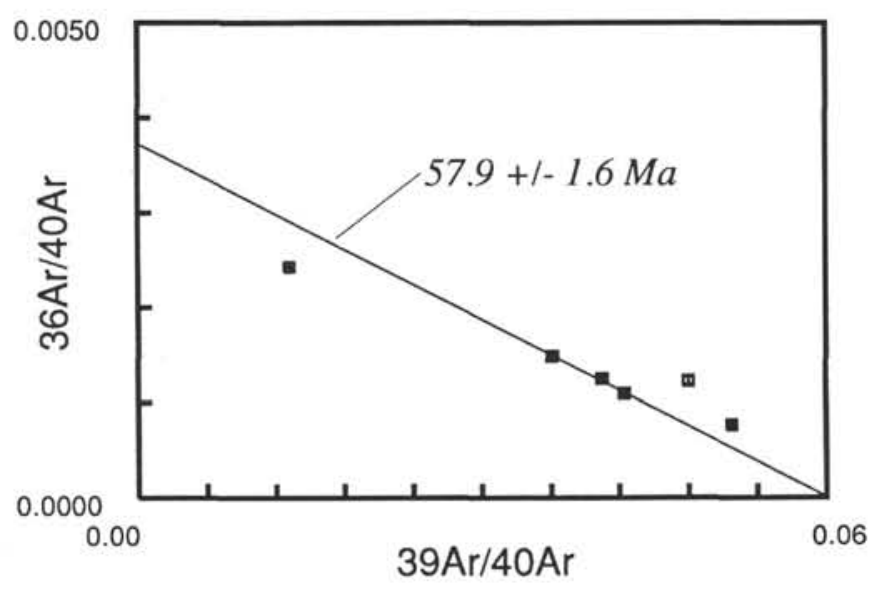

c Basalt $757 \mathrm{C}-12 \mathrm{R}-1,124-128 \mathrm{~cm}$

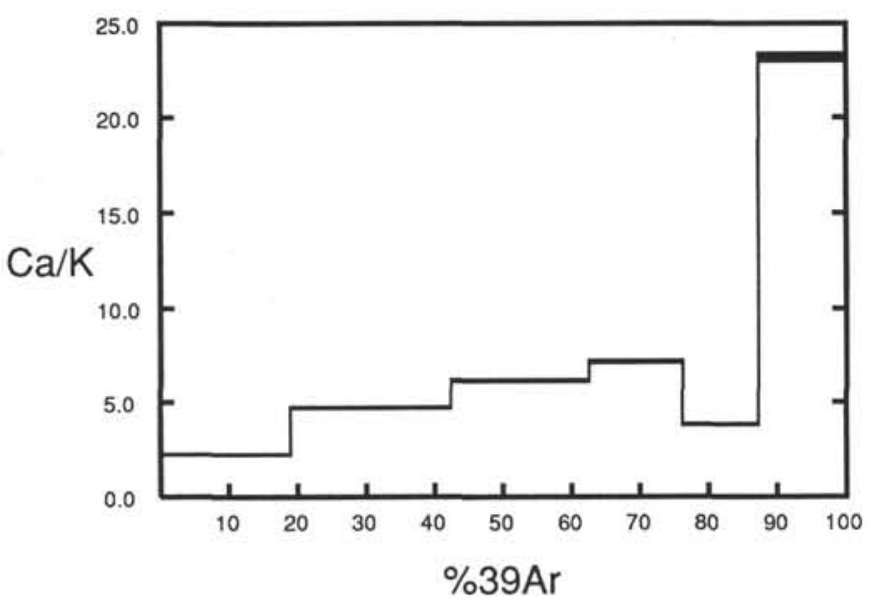

Figure 8. A. Apparent age spectrum (plateau) diagram. B. ${ }^{36} \mathrm{Ar} /{ }^{40} \mathrm{Ar}-{ }^{39} \mathrm{Ar} /{ }^{40} \mathrm{Ar}$ isochron diagram. C. Apparent $\mathrm{Ca} / \mathrm{K}$ release diagram for basalt Sample 121$757 \mathrm{C}-12 \mathrm{R}-1,124-128 \mathrm{~cm}$, from the Ninetyeast Ridge. Details as in Figure 2. close to $58 \mathrm{Ma}$. This matches the biostratigraphic age (late Paleocene) and the basement age predicted from modeling (Fig. 11).

Samples from the northern site on the Ninetyeast Ridge produced large quantities of atmospheric ${ }^{40} \mathrm{Ar}$ (probably from the extensive clay alteration) and step ages have large analytical uncertainties. Nevertheless, the two samples showed acceptable plateaus and concordant isochron ages in the range 81-83 Ma (Figs. 9, 10). The weighted mean site age is, then, $81.8 \pm 2.6 \mathrm{Ma}$, or earliest Campanian/latest Santonian, which is compatible with basal sediments. The modeled age for this site (79 Ma, Fig. 11) is also close to the measured age.

\section{CONCLUSIONS}

The new ages from the Ninetyeast and Broken Ridges further support the hotspot model for generation of these volcanic structures. The age range of the Ninetyeast Ridge is $\sim 38 \mathrm{Ma}$ at its southern end to slightly more than $82 \mathrm{Ma}$ at its northern end. The Broken Ridge formed a bit earlier $(\sim 88 \mathrm{Ma})$, in concert with the central portion of the Kerguelen-Heard Plateau. The earliest evidence of the hotspot is a flood basalt province, now dismembered into the Rajmahal Traps (117 Ma, Baksi, 1986) and the southern Kerguelen Plateau (exceeding Albian age, deduced from sediments drilled at Sites 748 and 750 (Schlich, Wise, et al., 1989)), and perhaps the Naturaliste Plateau (including the Bunbury basalts, southwestern Australia). Since $\sim 38 \mathrm{Ma}$, when seafloor spreading on the Southeast Indian Ridge separated the Ninetyeast Ridge from the hotspot, volcanism has been restricted to a small region of the slow-moving Antarctic plate, around the Kerguelen archipelago.

Computer modeling of hotspot tracks is based on the hypothesis that hotspots are maintained by stationary mantle plumes (Morgan, 1981; Duncan, 1981). South Atlantic hotspot tracks are clearly defined and new age determinations from the Walvis Ridge (O'Connor and Duncan, 1990) have resolved the history of African plate motion over the Tristan hotspot since $125 \mathrm{Ma}$ (the age of Parana-Etendeka flood basalt volcanism). Hence, rotation poles for the African plate over hotspots have been fitted to the African hotspot trails (Tristan, Bouvet, and Marion tracks) and rotation rates adjusted to match the new ages (Table 2). Hotspot tracks on the Indian and Antarctic plates are then predicted by adding the appropriate relative plate motions (Molnar et al., 1987) to the African rotations. Figure 11 illustrates such modeled tracks superimposed on bathymetric features in the south Atlantic and Indian oceans. The African tracks follow known volcanic lineaments closely. The predicted path of the Réunion hotspot follows the Mascarene Plateau (African plate) and the Chagos-MaldiveLaccadive ridge system, connecting to the Deccan flood basalts (Indian plate). Measured ages (Duncan and Hargraves, 1990; Duncan and Pyle, 1988) match predicted times of hotspot volcanism extremely well.

The position of the Kerguelen hotspot has been adjusted to best fit the Ninetyeast Ridge. If the hotspot is placed directly beneath the Kerguelen islands the resulting modeled track lies a few degrees to the east of the Ninetyeast Ridge. A position some 300 $\mathrm{km}$ to the west of the archipelago is permissible based on the long record of volcanism in the islands and slow clockwise rotation of Antarctica (Duncan, 1981), and a cluster of seamounts with a strong geoid anomaly at this location. The modeled track closely follows the Ninetyeast Ridge from 40 to $80 \mathrm{Ma}$ and six dated drilling sites lie close to predicted times of volcanism (note possible late-stage lavas at Site 756). This close correspondence between volcanic trails and modeled tracks is strong evidence that hotspots remain fixed for significant periods ( $100 \mathrm{~m} . \mathrm{y}$.) over large regions of the globe.

The Kerguelen hotspot began with vast outpourings of tholeiitic flood basalts at M0 anomaly time, or the beginning of the 

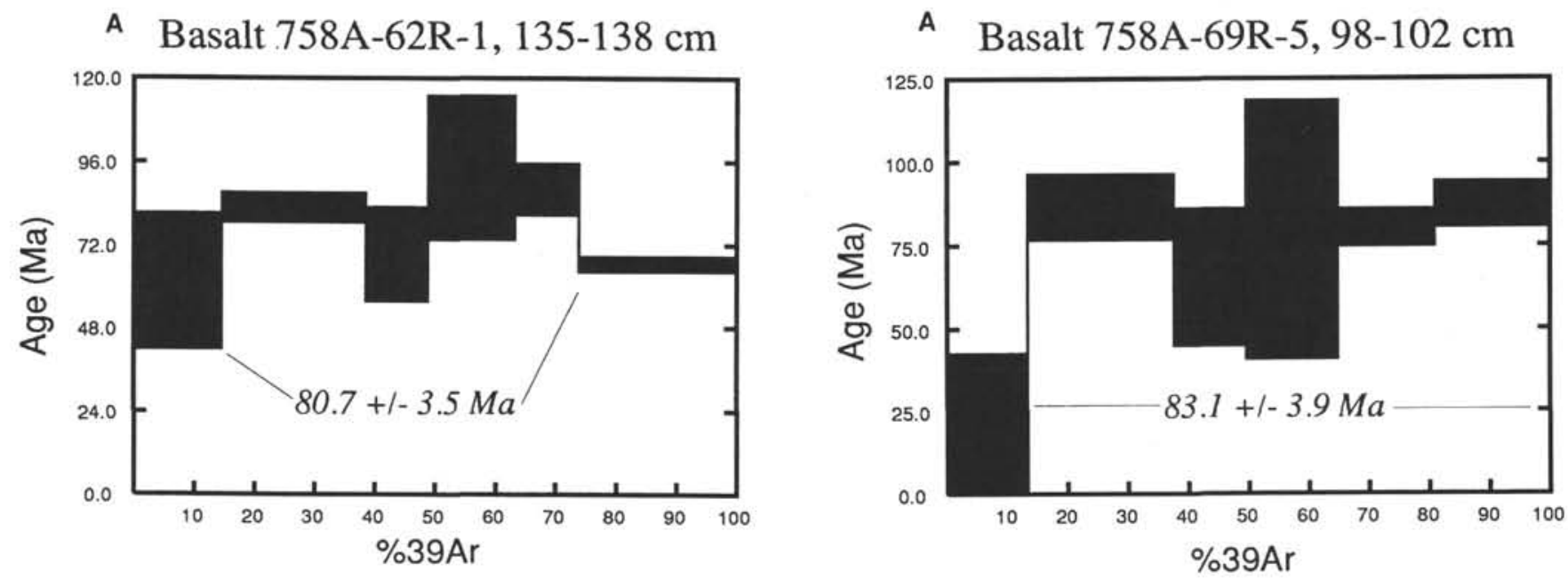

B Basalt 758A-62R-1, 135-138 cm

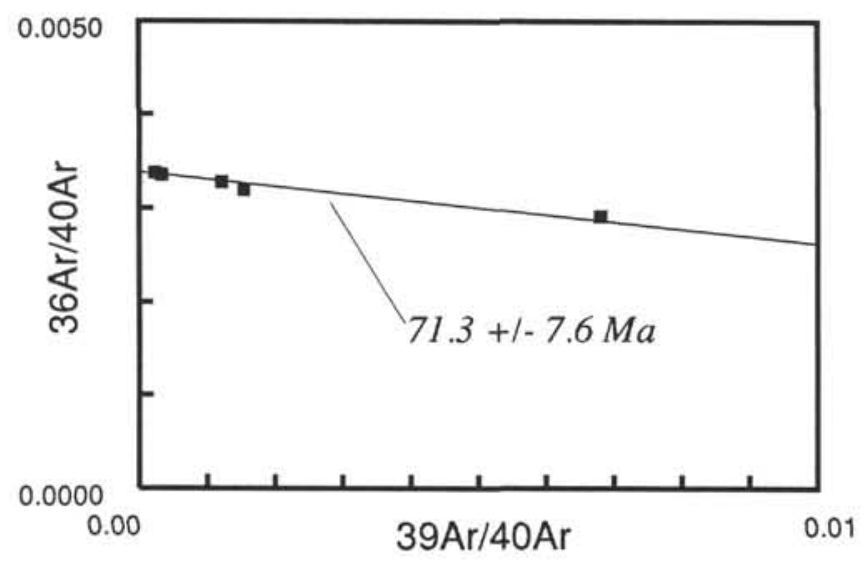

B Basalt 758A-69R-5, 98-102 cm

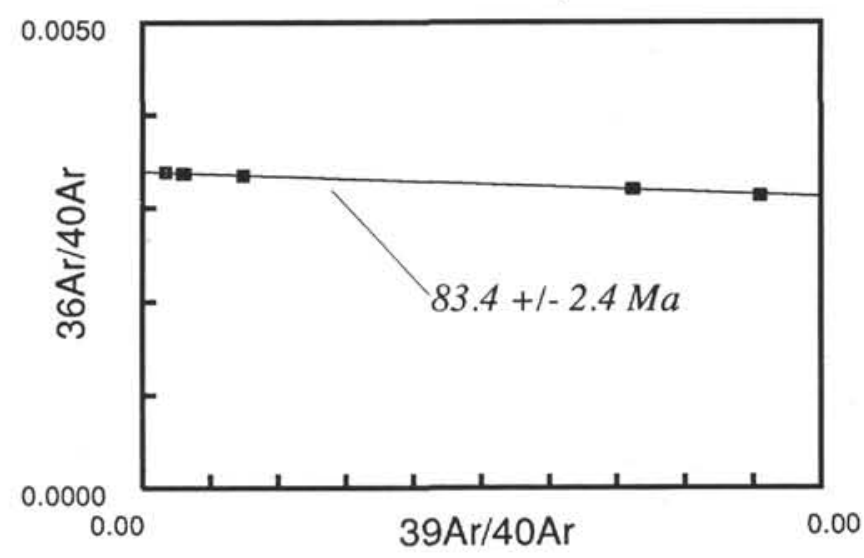

C Basalt $758 \mathrm{~A}-62 \mathrm{R}-1,135-138 \mathrm{~cm}$

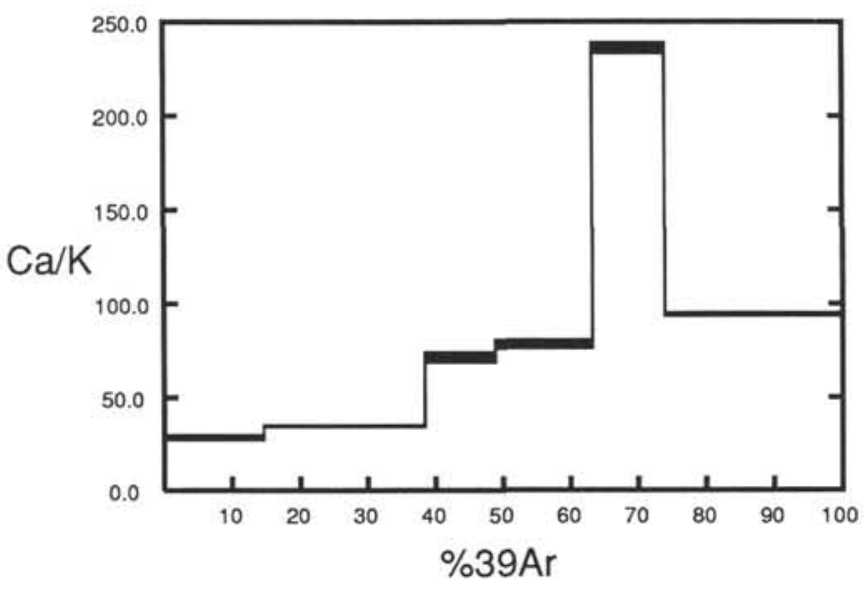

Figure 9. A. Apparent age spectrum (plateau) diagram. B. ${ }^{36} \mathrm{Ar} /{ }^{40} \mathrm{Ar}{ }^{39} \mathrm{Ar} /{ }^{40} \mathrm{Ar}$ isochron diagram. C. Apparent $\mathrm{Ca} / \mathrm{K}$ release diagram for basalt Sample 121758A-62R-1, 135-138 cm, from the Ninetyeast Ridge. Details as in Figure 2.

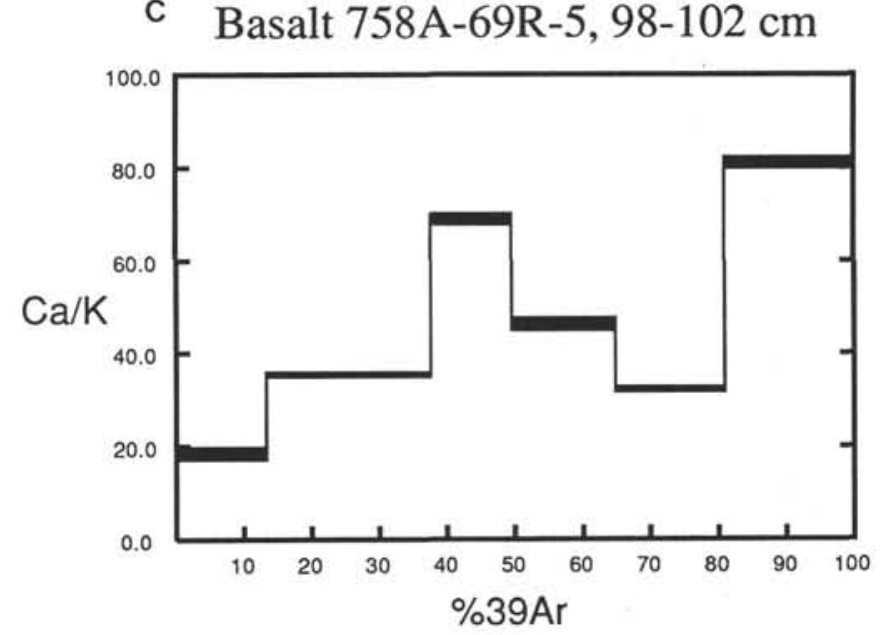

Figure 10. A. Apparent age spectrum (plateau) diagram. B. ${ }^{36} \mathrm{Ar} /{ }^{40} \mathrm{Ar}-$ ${ }^{39} \mathrm{Ar} /{ }^{40} \mathrm{Ar}$ isochron diagram. C. Apparent $\mathrm{Ca} / \mathrm{K}$ release diagram for basalt Sample 121-758A-69R-5, 98-102 cm, from the Ninetyeast Ridge. Details as in Figure 2. 


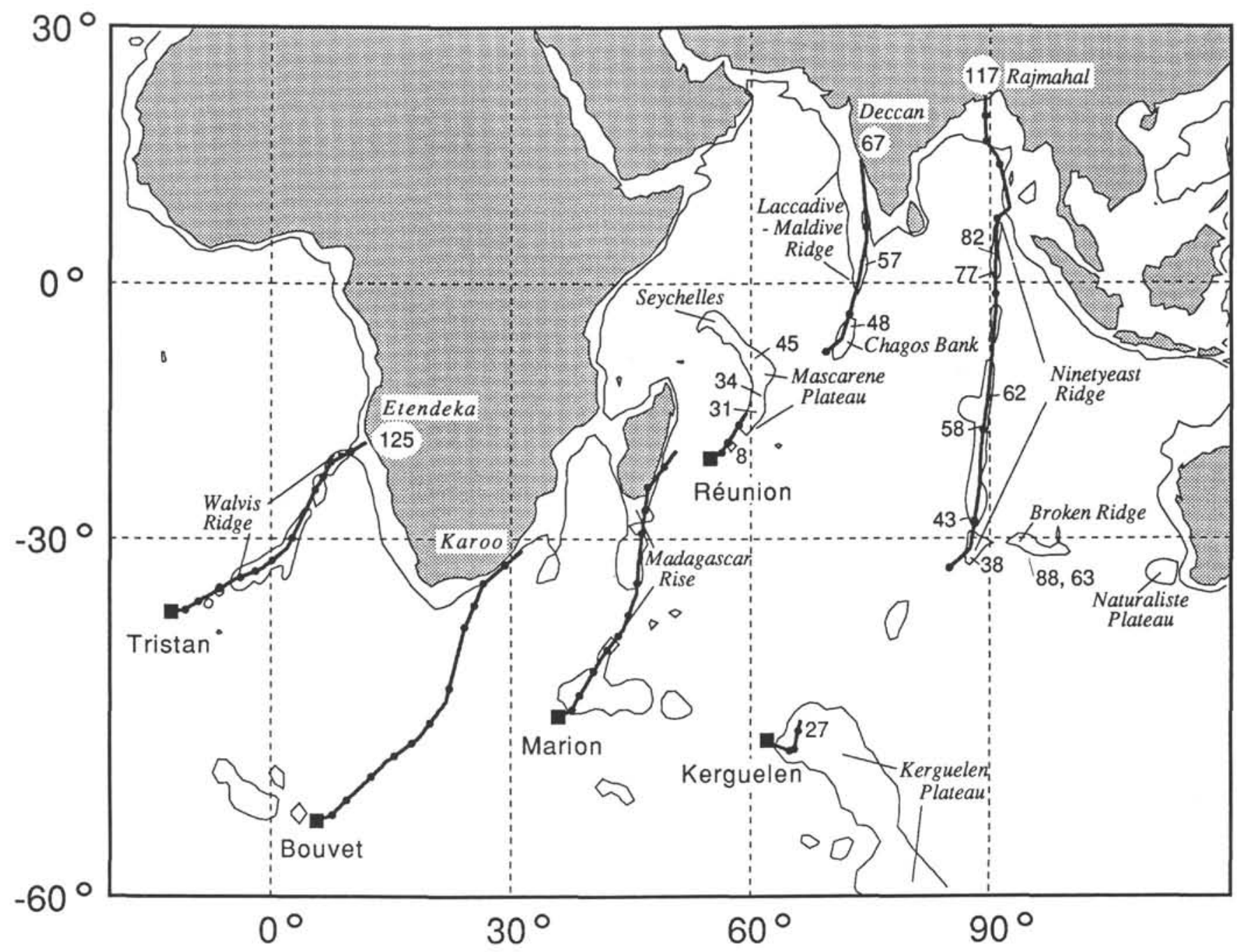

Figure 11. Computer-modeled tracks are calculated assuming hotspots are stationary. The predicted trails (heavy lines with solid dots at 10-m.y. age increments) are determined from African plate motion over South Atlantic hotspots (principally from dated sites on the Walvis Ridge, O'Connor and Duncan, 1990). Rotation poles are given in Table 2. The model tracks compare well with the actual lineaments and radiometric ages (indicated in Ma) of volcanic activity along the Réunion and Kerguelen hotspot tracks (Duncan and Hargraves, 1990; Duncan, 1978; Baksi, 1986). New ages for the Ninetyeast and Broken Ridges are shown. Hence, Atlantic and Indian Ocean hotspots have remained fixed with respect to one another since the Early Cretaceous. Flood basalts at the northern ends of the Réunion and Kerguelen tracks, and eastern end of the Tristan track resulted from hotspot initiation.

Cretaceous long normal polarity interval ("Quiet Zone"). These now comprise the Rajmahal Traps in eastern Indian ( $117 \pm 1 \mathrm{Ma}$; Baksi, 1986) and the southern Kerguelen Plateau (Davies et al., 1989). The Broken Ridge and conjugate central Kerguelen-Heard Plateau formed at about $88 \mathrm{Ma}$ as the early trace of this hotspot on the Australian/Antarctic plate, during northwest-southeast spreading between India and Australia (Royer et al., this volume). Beginning at about Anomaly 34 time ( $84 \mathrm{Ma}$ ) the spreading ridge geometry changed to allow rapid northward motion of India away from Australia/Antarctica. The hotspot lay north of, but close to, a spreading segment of this plate boundary and produced the Ninetyeast Ridge which was bounded to the east by a lengthening transform fault. Thus the older Broken Ridge, formed on the Australia plate, was juxtaposed with the younger southern Ninetyeast Ridge, formed on the Indian plate. Early and late elements of the hotspot have likewise been amalgamated into the Kerguelen Plateau on the Antarctic plate.

\section{ACKNOWLEDGMENTS}

J. K. Weissel provided dredge samples from the Broken Ridge. Neutron irradiation of samples at the OSU TRIGA reactor was facilitated by A. Johnson and T. Anderson. I thank L. G. Hogan for laboratory assistance and the JOI U. S. Science Advisory Committee and the National Science Foundation (grant no. OCE8812143 ) for funding.

\section{REFERENCES}

Baksi, A. K., 1986. ${ }^{40} \mathrm{Ar} /{ }^{39} \mathrm{Ar}$ incremental heating study of whole-rock samples from the Rajmahal and Bengal traps, eastern India. Terra Cognita, 6:161. (Abstract)

Barron, J., Larsen, B., et al., 1989. Proc. ODP, Init. Repts., 119: College Station, TX (Ocean Drilling Program).

Dalrymple, G. B., Clague, D. A., Vallier, T. L., and Menard, H. W., 1988. ${ }^{40} \mathrm{Ar} /{ }^{39} \mathrm{Ar}$ age, petrology, and tectonic significance of some seamounts in the Gulf of Alaska. In Keating, B. H., Fryer, P., Batiza, 
R., and Boehlert, G. W. (Eds.), Seamounts, Islands and Atolls. Am. Geophys. Union Monogr., 43:297-315.

Dalrymple, G. B., and Lanphere, M. A., 1969. Potassium-Argon Dating: San Francisco (W. H. Freeman).

Dalrymple, G. B., Lanphere, M. A., and Clague, D. A., 1981. Conventional and ${ }^{40} \mathrm{Ar} /{ }^{39} \mathrm{Ar} \mathrm{K}-\mathrm{Ar}$ ages of volcanic rocks from Ojin (Site 430), Nintoku (Site 432) and Suiko (Site 433) seamounts and the chronology of volcanic propagation along the Hawaiian-Emperor Chain. In Jackson, E. D., Koisumi, I., et al., Init. Repts. DSDP, 55: Washington (U.S. Govt. Printing Office), 659-676.

Davies, H. L., Sun, S.-S., Frey, F. A., Gautier, I., McCulloch, M. T., Price, R. C., Bassias, Y., Klootwijk, C. T., and Leclaire, L., 1990. Basalt basement from the Kerguelen Plateau and the trail of the Dupal plume. Contrib. Mineral. Petrol., 103:457-469.

Davies, T. A., Luyendyk, B. P., et al., 1974. Init. Repts., DSDP, 26: Washington (U.S. Govt. Printing Office).

Duncan, R. A., 1978. Geochronology of basalts from the Ninetyeast Ridge and continental dispersion in the eastern Indian Ocean. J. Volcanol. Geotherm. Res., 4:283-305.

1981. Hotspots in the southern oceans-an absolute frame of reference for motion of the Gondwana continents. Tectonophysics, $74: 29-42$.

Duncan, R. A., and Hargraves, R. B., $1990 .{ }^{40} \mathrm{Ar} /{ }^{39} \mathrm{Ar}$ geochronology of basement rocks from the Mascarene Plateau, Chagos Bank, and the Maldives Ridge. In Duncan, R. A., Backman, J., Peterson, L. C., et al.,Proc. ODP, Sci. Results, 115: College Station, TX (Ocean Drilling Program), 43-51.

Duncan, R. A., and Pyle, D. G., 1988. Rapid eruption of the Deccan flood basalts at the Cretaceous/Tertiary boundary. Nature, 333:841-843.

Fleck, R. J., Sutter, J. F., and Elliott, D. H., 1977. Interpretation of discordant ${ }^{40} \mathrm{Ar} /{ }^{39} \mathrm{Ar}$ age-spectra of Mesozoic tholeiites from Antarctica. Geochim. Cosmochim. Acta, 41:15-32.

Frey, F. A., Dickey, J. S., Jr., Thompson, G., and Bryan, W. B., 1977. Eastern Indian Ocean DSDP sites: correlations between petrology, geochemistry and tectonic setting. In Heirtzler, J. R., Bolli, H. M., Davies, T. A., Saunders, J. B., and Sclater, J. G. (Eds.), Indian Ocean Geology and Biostratigraphy: Am. Geophys. Union, 189-257.

Huneke, J. C., and Smith, S. P., 1976. The realities of recoil; ${ }^{39} \mathrm{Ar}$ recoil out of small grains and anomalous age patterns in ${ }^{39} \mathrm{Ar} /{ }^{40} \mathrm{Ar}$ dating. Geochim. Cosmochim. Acta, Suppl., 7:1987-2008.

Lanphere, M. A., and Dalrymple, G. B., 1978. The use of ${ }^{40} \mathrm{Ar} /{ }^{39} \mathrm{Ar}$ data in evaluation of disturbed K-Ar systems. In Zartman, R. E. (Ed.), Short Papers of the Fourth International Conference, Geochronology, Isotope Geology. Open-File Rep. U.S. Geol. Surv., 78-701:241-243.

LeClaire, L., Bassias, Y., Denis-Clochiatti, M., Davies, H. L., Gautier, I., Gensous, B., Giannesini, P.-J., Morand, F., Patriat, P., Ségoufin, J., Tesson, M., and Wannesson, J., 1987. Lower Cretaceous basalt and sediments from the Kerguelen Plateau. Geo-Mar. Lett., 7:169-176.

Luyendyck, B. P., 1977. Deep sea drilling on the Ninetyeast Ridge: synthesis and a tectonic model. In Heirtzler, J. R., Bolli, H. M., Davies, T. A., Saunders, J. B., and Sclater, J. G. (Eds.), Indian Ocean Geology and Biostratigraphy: Washington (Am. Geophys. Union), 165-187.

Luyendyck, B. P., and Rennick, W., 1977. Tectonic history of aseismic ridges in the eastern Indian Ocean. Geol. Soc. Am. Bull., 88:13471356.

Mahoney, J. L., Macdougall, J. D., Lugmair, G. W., and Gopalan, K., 1983. Kerguelen hot-spot source for Rajmahal Traps and Ninetyeast Ridge? Nature, 303:385-389.

McDougall, I., and Harrison, T. M., 1988. Geochronology and Thermochronology by the ${ }^{40} \mathrm{Ar}^{39}{ }^{39} \mathrm{Ar}$ Method: Oxford (Oxford Univ. Press).

Molnar, P., Pardo-Casas, R., and Stock, J., 1987. The Cenozoic and Late Cretaceous evolution of the Indian Ocean basin: uncertainties in the reconstructed positions of the Indian, African and Antarctic plates. Basin Res., 1:23-40.

Morgan, W. J., 1981. Hotspot tracks and the opening of the Atlantic and Indian Oceans. In Emiliani, C. (Ed.), The Sea (Vol. 7): New York (Wiley), 443-487.

Mutter, J. C., and Cande, S. C., 1983. The early opening between Broken Ridge and the Kerguelen Plateau. Earth Planet. Sci. Lett., 65:369376.
O'Connor, J. M., and Duncan, R. A. 1990. Evolution of the Walvis Ridge and Rio Grande Rise hotspot system: implications for African and South American plate motions over hotspots. J. Geophys. Res., 95:17475-17502.

Peirce, J. W., 1978. The northward motion of India since the Late Cretaceous. Geophys. J. R. Astron. Soc., 52:277-312.

Peirce, J., Weissel, J., et al., 1989. Proc. ODP, Init. Repts., 121: College Station, TX (Ocean Drilling Program).

Samson, S. D., and Alexander, E. C., Jr., 1987. Calibration of the interlaboratory $40 \mathrm{Ar} / 39 \mathrm{Ar}$ dating standard, MMhb-1. Chem. Geol., $66: 27-34$.

Schlich, R., Wise, S. W., Jr., et al., 1989. Proc. ODP, Init. Repts., 120: College Station, TX (Ocean Drilling Program).

Turner, G., and Cadogan, P. H., 1974. Possible effects of ${ }^{39} \mathrm{Ar}$ recoil in ${ }^{40} \mathrm{Ar} /{ }^{39} \mathrm{Ar}$ dating of lunar samples. Geochim. Cosmochim. Acta, Suppl., 5:1601-1615.

von der Borch, C. C., Sclater, J. G., et al., 1974. Init. Repts. DSDP, 22 Washington (U.S. Govt. Printing Office).

Walker, D. A., and McDougall, I., $1982 .{ }^{40} \mathrm{Ar} /{ }^{39} \mathrm{Ar}$ and $\mathrm{K}$-Ar dating of altered glassy volcanic rocks: the Dabi Volcanics. Geochim. Cosmochim. Acta, 46:2181-2190.

Whitford, D. J., and Duncan, R. A., 1978. Origin of the Ninetyeast Ridge - Sr isotope and trace element evidence. In Zartman, R. E. (Ed.), Short Papers of the Fourth International Conference, Geochronology, Cosmochronology, Isotope Geology. Open-File Rep. U.S. Geol. Surv., 78-701:451-453.

York, D., 1969. Least-squares fitting of a straight line with correlated errors. Earth Planet. Sci. Lett., 5:320-324.

Date of initial receipt: 7 March 1990

Date of acceptance: 24 September 1990

Ms 121B-162

Table 2. Rotation poles for South Atlantic and Indian Ocean opening, hotspot reference frame.

\begin{tabular}{|c|c|c|c|}
\hline $\begin{array}{l}\text { Time interval } \\
\text { (Ma, Chron) }\end{array}$ & $\begin{array}{l}\text { Latitude } \\
\qquad\left({ }^{\circ} \mathrm{N}\right)\end{array}$ & $\begin{array}{l}\text { Longitude } \\
\left({ }^{\circ} \mathrm{E}\right)\end{array}$ & $\begin{array}{c}\text { Rotation } \\
\text { (ccw) }\end{array}$ \\
\hline \multicolumn{4}{|c|}{ African plate over hotspots } \\
\hline $0-11(C 5)$ & 65.0 & -30.0 & 2.5 \\
\hline $0-21$ (C6) & 51.0 & -45.0 & 4.7 \\
\hline $0-36(\mathrm{C} 13)$ & 35.0 & -45.0 & 8.0 \\
\hline $0-42(\mathrm{C} 18)$ & 37.5 & -42.5 & 9.0 \\
\hline $0-58(\mathrm{C} 26)$ & 40.0 & -40.0 & 10.7 \\
\hline $0-66(\mathrm{C} 30)$ & 35.0 & -40.0 & 14.5 \\
\hline $0-80$ (C33R) & 31.0 & -50.0 & 20.0 \\
\hline $0-100$ & 25.0 & -47.0 & 25.5 \\
\hline $0-118(\mathrm{M} 0)$ & 25.0 & -45.0 & 30.0 \\
\hline
\end{tabular}

Indian plate over hotspots ${ }^{\mathrm{a}}$

$\begin{array}{lrrr}0-11 \text { (C5) } & 41.0 & 25.9 & 6.8 \\ 0-21 \text { (C6) } & 31.4 & 26.9 & 12.8 \\ 0-36 \text { (C13) } & 24.2 & 26.4 & 21.8 \\ 0-42 \text { (C18) } & 26.4 & 27.2 & 25.6 \\ 0-58(\mathrm{C} 26) & 26.9 & 13.5 & 36.4 \\ 0-66(\mathrm{C} 30) & 20.4 & 10.3 & 48.6 \\ 0-80 \text { (C33R) } & 19.3 & 2.8 & 62.5 \\ 0-100 & 14.3 & 5.3 & 72.5 \\ 0-118(\mathrm{M} 0) & 13.9 & 3.7 & 77.0\end{array}$

Antarctic plate over hotspots ${ }^{\mathrm{a}}$

\begin{tabular}{lrrr}
$0-11$ (C5) & 61.9 & -115.4 & 3.5 \\
$0-21(\mathrm{C} 6)$ & 74.3 & -104.0 & 3.9 \\
$0-36(\mathrm{C} 13)$ & 72.7 & -63.5 & 4.7 \\
$0-42$ (C18) & 85.9 & -3.4 & 4.7 \\
\hline
\end{tabular}

a Relative motion rotation poles from Molnar et al. (1987). 